\title{
Cultural Heritage and Citizenship: Curating the First Afrolatino Film Festival in the US
}

\author{
Amilcar Maceo Priestley • The Afrolatin@ Project, Inc.
}

\begin{abstract}
The Liberación Film Festival which launched in 2017 is the first large scale curation of a film festival in the US which centers the experiences of 150-200 million Afrolatinamericans and Afrolatinxs. In this paper, we discuss the sociological and political framework of the Festival's existence and share the Festival's film selection process which aims to reflect and connect cultural and artistic expression with important aspects of Afrolatinamerican and Afrolatinx historical and contemporary social movement building. The working principle behind the Festival's curation process, "culture as politics", is based on the idea that we can best utilize cultural heritage to contest anti-blackness in Latin America when it is presented with historic, social and political context. The Festival serves not only as a showcase of cultural heritage, but is itself cultural heritage, challenging the narratives of citizenship and belonging seen in traditional visual representations of Latinidad. The Festival also provides a space to showcase and celebrate upcoming Afrolatinx and Afrolatinamerican filmmakers, actors, actresses, documentarians, storytellers and others in the field of film.
\end{abstract}

"As proclaimed by the General Assembly in its resolution 68/237, the theme of the International Decade is 'People of African descent: recognition, justice and development.' The international community, international and regional organizations, in particular relevant United Nations programmes... should give high priority to programmes and projects specifically tailored for combating racism and racial discrimination against people of African descent... and should, inter alia:

(a) Take measures to raise awareness about the International Decade, including through awareness-raising campaigns, and organizing and supporting other activities, bearing in mind the theme of the Decade;...

(h) Support initiatives and projects aimed at honouring and preserving the historical memory of people of African descent;...”

In July 2018, the Afro-Latino Festival NYC, an annual event celebrating Afrolatinx cultural heritage preservation and political, socio-economic advancement organized the 2nd annual Liberación Film Festival. This festival within a festival included a full day of screenings, director Q\&As and panel discussions, as well as vendors and music celebrating Afrolatinidad. The Festival screened more than 15 films including a First Look, a World Premiere, and 5 US premieres hailing from 7 countries. It was the first time something of this scope had been done in the US. We reached this point because of the groundwork laid over the last 8 years.

This paper explores the political positioning of the Festival and the curation process and the political context of the film tracks and selections within the framework of contemporary Afro-Latin American social movements. As we enter the halfway mark for the U.N. International Decade for Afrodescendants (2015-2024), the Film Festival aims to highlight the principle of "recognition".

\section{POLITICAL FRAMEWORK}

The U.N. International Decade for Afrodescendants was declared in 2013 . Following a 15 year push by many organizations which devised and implemented the Durban Plan to combat racism globally, this was established following the 2001 World Conference Against Racism Discrimination and Xenophobia in Durban South Africa. Historically, geopolitical 
agendas have driven the development of film festivals, especially in Europe. While these agendas are "powerful forces driving and shaping festivals, they are also shown to intersect with cultural objectives, economic interests and specific (inter) national historical circumstances."

In Latin America, this takes on added importance in how Afrolatinamericans are represented, given how the concept of national identity has been constructed. Nation- states are often created and fortified based on cultural norms and practices which are established by certain experiences which are deemed to be specific to a given community. Benedict Anderson defines the nation as "an imagined political community". ${ }^{3}$

White supremacy and racial caste systems in the region were critical to colonial era economic development and societal formation. They were also foundational to the formation of the nation-state in a region as vastly heterogeneous as the Western Hemisphere. In contrast to the racial hierarchy created by the one-drop rule in the US, several racial ideologies developed in Latin America contributing to the concept of national identity; in Mexico, Jorge Vasconcelos developed the concept of the raza cosmica, in Brazil, Gilberto Freyre developed lusotropicalism, in Cuba the ideology of race mixing was deemed superior, ${ }^{4}$ while indigenismo flourished in both Mexico and Peru. ${ }^{5}$

These racial theories helped consolidate national identity around the idea that race mixture or "miscegenation" would lead to the eventual whitening of Latin America. Thus, national identities of most Latin American countries until recently have been designed to celebrate an imagined cultural homogeneity, while rejecting or folklorizing their African, as well as indigenous roots. ${ }^{6,7}$ This "rejection" is best evidenced in the cultural realm by the ways in which national tourism boards throughout the region generally and historically promoted a white/ mestizo image of their respective countries. ${ }^{8}$

The "folkorization" is best evident in the ways in which cultural heritage is exported including music, film, television and sports talent. One of the key ways culture is used to reinforce nationalism is through the creation of a set of cultural markers deemed to be symbolic of the nation. Those markers are often designed to reinforce social hierarchies and cultural homogeneity. The entertainment, advertising and museum industries in turn provide the means of dissemination of the official narrative of the national culture. ${ }^{9}$

It is within this framework that the Liberación Film Festival intends to reimagine the cultural markers through its curation of films that tell the stories of black Latin America. ${ }^{10}$

The mediums of film and increasingly the digital, serve an important role in memorializing cultural heritage. "[T]he historicity of heritage needs to be formalised through material symbolism, which makes the intangible and ephemeral into something that has material form, be it on paper, a book, an audiovisual recording, particular elements of a festival, or an archive". ${ }^{11}$ The Festival should thus be viewed as a celebration of both the inherent preservation and storytelling value of film, as well as the experiences and intangible cultural heritage the films depict.

\section{UNITED STATES AND LATIN AMERICA FESTIVAL LANDSCAPE}

In Latin America, the largest exporters of film have been Mexico, Argentina, Brazil, Colombia, and Chile. ${ }^{12}$ More recently Panama, Haiti, Cuba, and the Dominican Republic, have entered the marketplace of cultural cinema.

Over the last eight years we have watched to see if anyone would present a film festival that could share our stories. A brief survey shows other festivals have a spattering of films on black issues or even with black protagonists but none, at least those in the US, have centered Afrolatinx experiences (we did not delve into the behind the camera personal so this critique is limited to the representation in front of the camera).

Until recently, Latino film festivals in the US, often organized according to country, rarely had representation of Afrolatinx or Afrolatinamericans. Interestingly, the Dominican Film Festival in New York has sought to tackle tough racial issues that resonate on the island including the 2013 decision by the Tribunal Courts of the Dominican Republic to revoke the citizenship of certain Haitians, a debate often framed in terms of nationalism and national sovereignty. More recently, they have included films with Afro-Dominican protagonists or that delve into issues of race and identity. Within the US, some black festivals have sought to incorporate more diaspora perspectives which included others of African descent in the Western Hemisphere. For example, the African Diaspora International Film Festival (ADIFF) held in several cities nationwide has consistently sought to include some representation of films about the Black experience in Latin America. The Blackstar Festival in Philadelphia in 2017 awarded its Favorite Documentary Short Award to Baobab Flowers a film by a AfroBrazilian/Peruvian director Gabriela Watson. The Pan African Film Festival and Arts Festival in Los Angeles and the American Black Film Festival in Miami have both screened Toussaint L'Ouverture," Jimmy Jean Louis Goes to Tijuana on the migrant crisis of Haitians in Tijuana, Mexico.

In Latin America, there are several festivals which have emerged in recent years in direct response to the call of the Decade for greater "recognition". In Brazil, historically, representation of Afro-Brazilians has been invisibilized ${ }^{13}$ or relegated to portraying the black maid (1960's and 70s); the loyal bodyguard (1980s); the super-obedient slave or non-thinking slave (1980s and 90s)..$^{14}$

Since the Decade began there have been a number of film festivals in Latin America focusing on more representative depictions of the black experience; these tend to be country specific with some selections from the rest of the diaspora also shown. For example: in Brazil, the "Mostra de Cinema Negro" (2016-2017) ${ }^{15}$; in Argentina, "Festival Nacional de Cultura 
Afro, la Plata" and the "Festival Mandinga" organized by the Centro Cultural de la Memoria Haroldo Conti (2014-2017) ${ }^{16}$ In Colombia there are several, the "Muestra Afro" in Bogota ${ }^{17}$, the "Festival de Cinema Afro Kunta Kinte" in Medellin"18; and the "Festival de Cine Afro Ananse" in Cali ${ }^{19}$. In Panama, there is the "Muestra de CineAfro." 20

Many of these are organized by members of the black community, although a few are organized by national or regional governments or under their auspices. Through the Liberación Film Festival we will contribute to this list of Festivals that share the Black and Latinx experience, while also centering Afrolatinidad in a way not previously done in the US.

\section{LIBERACIÓN FILM FESTIVAL CURATION PROCESS}

The subject matter of the Festival tracks are designed to: a) highlight pressing matters that our community faces, b) demonstrate the commonality in experiences across borders, and c) assist in highlighting up and coming Afrolatinx creatives and talent. The purpose of curating this specific set of themes is to highlight storytelling that contextualizes the historical and political narratives. We first develop the tracks that will be used to decide on the various films. These are based on the conversations that are being held within the movement in Latin America as well as those being held by Afrolatinxs in the US seeking to mobilize. In 2015 we presented Afrolatinos: The Untold Story an important primer on understanding Afrolatinidad. This was the launch year for the U.N. Decade and the film provided a general overview of Afrolatinidad. In 2016, we screened Nana Dijo. This occurred at the height of the Black Lives Matter Movement and its corresponding "Jovem Negro Vivo" campaigns in Brazil and the "Las Vidas Negras Importan" efforts elsewhere in the region. In 2017, during our Women of the Diaspora celebration, we presented three films, two by women directors from Brazil (Afrotrip, Dir. Gabriela Watson) and Curação (Sombra di Kolo, Dir. Angela Roe), and one which discussed border politics, race and violence on the island of Hispaniola (Death by a Thousand Cuts, Juan Mejia).

In 2018, in addition to expanding beyond documentaries to include shorts and fictional works, the screenings were a reflection of our theme, Identity and Beyond. They included short film tracks on Displacement \& Resilience, Brazil, Social Movements, Identity and Cultural Heritage. Our goal has been to connect the existing movement in Latin America with Afrolatinxs in the US who seek to develop a US based movement. By highlighting the issues faced by Afrolatinamericans in Latin America, we hope to broaden the renewed conversation in the US beyond this current phase of identifying as Afrolatinx to develop a better understanding of the implications in asserting Afrolatinidad from a socio-political angle.
The films shown during the 2018 Social Movements track included Awakening, on Black youth from Ferguson, MO and Buenaventura, Colombia, embark on a journey to discover what it means to be Black in different corners of the world. The documentary explored the construction of race through interviews with academics and the average person on the street in various countries in the region. In Braids: The Politics of Aesthetics, women involved in the natural hair movement in Panama shared how the movement embraces the aesthetics of hair itelf, but also addresses socio-economic issues of employment opportunity and public discrimination which arise from those aesthetics. In the Displacement and Resilience track, films explored issues of displacement as a result of natural disaster, Jimmy Jean Louis Goes to Tijuana (2010 Haiti earthquake) and AfroFuturos (Hurricane Maria, Puerto Rico 2017) or development, Drums of Resistance Boquilla, Colombia (hotel developers displacement of black communities in coastal Cartagena, Colombia 2018). Many of these issues resonate in black and brown communities in the US and throughout Latin America.

The Festival also serves to celebrate and provide networking and skill building opportunities for on and off-screen talents. In 2018 we had two upcoming Brazilian director premiere their works and we also screened Awakening as a First Look which provided a platform for the films' producers to seek additional production funding.

\section{CONCLUSION}

In conclusion, the Liberación Film Festival serves an important role in communicating shared experiences, breaking the narrative of belonging by revalorizing black cultural heritage and providing a platform for Afrolatinx talent who may otherwise not receive such opportunities. In the Decade for People of African Descent, documenting and showcasing these audiovisual works which explore contemporary and historic narratives of race in Latin America will ultimately serve to strengthen the movement in Latin America and also help harness a renewed energy here in the US that has emerged in the last five years. 


\section{NOTES}

1. Programme of activities for the implementation of the International Decade for People of African Descent UN RES 69/16.2014. https://www.un.org/en/events/africandescentdecade/pdf/A.RES.69.16_IDPAD.pdf

2. Political Aspects of Film Festival History. Film Festival Research Network http://www.filmfestivalresearch.org/ index.php/ffrn-bibliography/1-film-festivals-the-longview/1-2-political-aspects-of-fil m-festivals-history/

3. Anderson, Benedict. Imagined Communities: Reflections on the Origin and Spread of Nationalism. Verso Books. 1991.

4. Hénonin, Abel Muñoz and Torres, César Albarrán. "La paradoja del cine latinoamericano contemporáneo (Presentación)”. December 13, 2018, Iconica pensamiento filmica. http://revistaiconica.com/ la-paradoja-del-cine-latinoamericano-contemporaneo/

5. De La Cadena, Marisol. 2000. Indigenous Mestizos: The Politics of Race and Culture in Cuzco, Peru, 1910-1991. Durham, Duke University Press. Pp 15-17.

6. De La Fuente, Alejandro, September 24, 2007. "The Resurgence of Racism in Cuba" NACLA https://nacla. org/article/resurgence-racism-cuba)

7. Changes to the national constitutions of Colombia, Ecuador, Venezuela, and Bolivia to acknowledge their pluri-ethnic and multi-cultural societies began in 1991.

8. De la Fuente, Id.

9. De La Fuente, Id.

10. Dixon, Kwame. "Afro-Cinema in Latin America: A new cultural renaissance”. Hemispheric Institute. E-Misférica 5.2 Race and Its Others. Volume 5 Issue 1, 2008. http:// hemisphericinstitute.org/hemi/en/e-misferica-52/dixon
11. Kuumta, Kristin, Cultural Heritage: An Introduction to Entanglements of Knowledge, Politics and Property Estonian Literary Museum, Estonian National Museum, University of Tartu 5 ISSN 1736-6518 Vol. 3 (2): 5-12 2009

12. Hénonin and Torres, Id.

13. Dandarra, Cinema de Preto, 2004. Retrieved from https://vimeo.com/17489319

14. Dixon, Id.

15. Mostra de Cinema Negro chega à $2^{\mathrm{a}}$ edição em Cuiabá. Midia News. December 18, 2017 http://www.midianews. com.br/cotidiano/mostra-de-cinema-negro-chega-a-2edicao-em-cuiaba/314121

16. Centro Cultural de la Memoria Haroldo Conti, Secretary of Human Rights and Pluralistic Culture, Ministry of Justice and Human Rights. November 2017. http://conti. derhuman.jus.gov.ar/2017/11/festival-mandinga.php

17. El Cine Afro Se Toma Cinematica Distrital. May 30, 2018. http://www.contagioradio.com/ cine-afro-muestra-articulo-5366o/

18. Villarreal, Jaime Darío Zapata. Festival International de Cinéma Afro Kunta Kinte à Medellín. Septmber 7, 2016 http://guyzoducamer.afrikblog.com/ archives/2016/09/07/34293975.html

19. Festival de Cine Afro Ananse 2011-2018. https://anansefestival.org

20. Chang, Astrid. "Cine afro se apodera de las calles en Colón.” La Estrella de Panamá March 27, 2019 http://laestrella.com.pa/vida-cultura/cultura/ cine-afro-apodera-calles-colon/24113447 